\title{
Guide to Systematizing Support for Students with Disabilities in Postsecondary EFL
}

Guía para sistematizar el apoyo a estudiantes con dificultades en EFL postsecundaria

Guia para sistematizar o apoio a estudantes com dificuldades em EFL no ensino superior

Davey YOUNG

https://orcid.org/0000-0002-8837-0924

Sophia University, Japan

dyoung@sophia.ac.jp

DOI: 10.5294/laclil.2020.13.1.2

To reference this article (APA) / Para citar este artículo (APA) / Para citar este artigo (APA) Young, D. (2020). Guide to systematizing support for students with disabilities in postsecondary EFL. Latin American Journal of Content \& Language Integrated Learning, 13(1), 26-42. https://doi.org/10.5294/laclil.2020.13.1.2 
ABSTRACT. Despite the ubiquitous presence of students with disabilities (SWDs) enrolled in institutes of higher education around the world, English as a Foreign Language (EFL) programs are often underequipped to provide them with appropriate and effective disability services and inclusive instruction. Given the general uncertainty among EFL professionals of how to provide such services and instruction, and considering that postsecondary EFL learning environments can differ considerably from context to context, it may be useful for language program leaders to create context-specific support systems to serve SWDs enrolled in their courses. The present paper provides a set of practical guidelines for establishing an institutional or departmental policy and procedures for ensuring a continuum of services to SWDs in contexts where such measures do not already exist, as is the case in many postsecondary EFL learning environments around the world. These guidelines are presented as a set of eight steps in a suggested sequence of execution: identify existing policies or create new ones, identify and determine the availability of resources, identify and remove barriers in the learning environment, assign clear roles and responsibilities for leadership, create a framework for service delivery, include a provision for post-implementation evaluation, offer opportunities for professional growth and creation of expertise, and share best practices with practitioners in other contexts.

Keywords (Source: Unesco Thesaurus): Students with disabilities; learning disabilities; English as a foreign language; inclusive practice; inclusive education; higher education; language program administration.

RESUMEN. A pesar de la presencia omnipresente de estudiantes con dificultades matriculados en institutos de educación superior en todo el mundo, los programas de EFL a menudo no cuentan con los equipos necesarios para brindarles instrucción inclusiva y servicios de discapacidad adecuados y efectivos. Dada la incertidumbre general entre los profesionales de EFL sobre cómo proporcionar dichos servicios e instrucción, y teniendo en cuenta que los entornos de aprendizaje de EFL postsecundarios pueden diferir considerablemente de un contexto a otro, puede resultar útil para los líderes de programas de idiomas el crear sistemas de apoyo específicos de contexto para los estudiantes con dificultades inscritos en sus cursos. Este artículo ofrece a un conjunto de pautas prácticas para establecer una política y procedimiento institucional o departamental para garantizar la continuidad de los servicios a los estudiantes con dificultades en contextos donde dichas medidas todavía no existen, como es el caso en muchos entornos de aprendizaje de EFL postsecundarios a nivel mundial. Estas pautas se presentan como un conjunto de ocho pasos en una secuencia sugerida de ejecución: identificar las políticas existentes o crear nuevas, identificar y determinar la disponibilidad de recursos, identificar y eliminar barreras en el entorno de aprendizaje, asignar roles y responsabilidades claros para el liderazgo, crear un marco para la prestación de servicios, incluir disposiciones para la evaluación posterior a la implementación, ofrecer oportunidades para el crecimiento profesional y la creación de experiencia y compartir las mejores prácticas con profesionales en otros contextos.

Palabras clave (Fuente: tesauro de la Unesco): estudiantes con dificultades; dificultad en el aprendizaje; inglés como lengua extranjera; prácticas integradoras; educación integradora; enseñanza superior; administración de un programa de lenguaje.

RESUMO. Apesar da presença onipresente de alunos com dificuldades matriculados em institutos de ensino superior em todo o mundo, os programas de EFL geralmente não têm o equipamento necessário para fornecer a eles uma instrução inclusiva e serviços de deficiência adequados e eficazes. Dada a incerteza geral entre os profissionais de EFL sobre como fornecer esses serviços e instrução e como os ambientes de aprendizado de EFL no ensino superior podem diferir consideravelmente de um contexto para outro, pode ser útil para os líderes do programa de idiomas criar sistemas de suporte específicos ao contexto para alunos com dificuldades matriculados em seus cursos. Este artigo fornece um conjunto de diretrizes práticas para o estabelecimento de uma política e procedimento institucional ou departamental para garantir a continuidade dos serviços para alunos com dificuldades em contextos em que essas medidas ainda não existem, como é o caso em muitos contextos de aprendizagem de EFL no ensino superior no mundo. Essas diretrizes são apresentadas como um conjunto de oito etapas em uma sequência sugerida de execução: identificar as políticas existentes ou criar novas políticas, identificar e determinar a disponibilidade de recursos, identificar e remover barreiras no ambiente de aprendizagem, atribuir funções e responsabilidades claras à liderança, criar uma estrutura para a prestação de serviços, incluir provisões para avaliação pós-implementação, oferecer oportunidades para o crescimento profissional e a construção de experiência e compartilhar as melhores práticas com profissionais em outros contextos.

Palavras-chave (Fonte: tesauro da Unesco): estudantes com dificuldades; dificuldade em aprender; inglês como língua estrangeira; práticas integrativas; educação inclusiva; ensino superior; administração de um programa de idiomas. 


\section{Introduction}

It is estimated that over one billion people worldwide experience disability in some form (WHO, 2019). All around the world, people with disabilities are frequently denied educational opportunities or face significant barriers in receiving education (UN News, 2016). While it is difficult to gain a comprehensive global view of people with disabilities entering institutes of higher education (IHEs), barriers identified in primary and secondary contexts, including the ability to receive any education at all, persist for students with disabilities (SWDs) seeking postsecondary education around the world. This includes both developing (Morley \& Croft, 2011) and developed countries (Chiwandire \& Vincent, 2019). A recent survey of 71 countries' higher education equity policies found that 58 of these countries specifically mention SWDs in their policies for promoting equity in higher education; however, only eight of these counties elaborate on the relevant policy to provide promotion strategies, define concrete targets for enrollment, or enact systems to help SWDs complete their degrees (Salmi, 2018). As a result, ensuring that SWDs receive structured support is a responsibility often left to individual IHEs or their departments, with little or no accountability from a policy perspective.

As practitioners in postsecondary EFL contexts around the world set out to provide support for SWDs enrolled in their courses, they may find themselves at something of a loss. In addition to the absence of any clear policy guidance, postsecondary EFL professionals often lack training in inclusive practice or special education. Furthermore, most of the literature on the intersection of language learning and special education is specific to primary or secondary ESL contexts in inner circle countries like the United States, the United Kingdom, and Australia. Many of the findings or suggestions in this body of research are not directly transferable to postsecondary EFL contexts in outer or expanding circle countries, as these contexts differ considerably in student population, learning goals and pedagogy, teacher preparedness, and administration both from inner circle countries and from each other.

Finally, rapidly evolving, and at times divergent, paradigms for framing the domains of both language learning and special education make 
it difficult for practitioners to situate their instruction within broadly established norms, as well as to identify and participate in a unified community of practice. For instance, do English language teachers in outer or expanding circle countries teach English as a foreign language, English as a lingua franca, Global Englishes, World Englishes, or English as an international language? Will they encounter students with disabilities, specific learner differences, or special educational needs? Nomenclature reflects disagreement about how to regard the broader field of English language education, disability, and students within each domain at a fundamental level. The debate around this nomenclature can be fierce and personal and, while necessary for finding a clear path towards optimal inclusive practice in the future, can confound efforts in the present. Acknowledging that the terms may be problematic, the present paper will primarily use the terms EFL and SWD for their concreteness and frequency of use in communities of practice across the two educational domains with which it is concerned.

Despite the complications listed above, language program leaders are well placed to help close some of the gaps in service provisions for SWDs enrolled in postsecondary EFL coursework, as many such practitioners oversee curricula, faculty, and students simultaneously. What follows are a set of eight guidelines for language program leaders, with special regard for those in postsecondary EFL contexts, for systematizing support for SWDs. For purposes of practicality and portability across contexts, these guidelines are organized as steps in a suggested sequence of execution. These guidelines have been written with a social justice model of education in mind, as this model seeks to account for the needs of all students while avoiding discrimination, whether intentional or inadvertent, in pedagogy and practice (Adams, 2016).

\section{Step 1. Identify existing policies or create new ones}

If they do exist, policies will differ from context to context. They may relate to legal requirements for making accommodations for SWDs, institutional guidelines, or both. Regardless of the specifics, such policies should guide all subsequent decisions regarding accommodations and services for SWDs enrolled in postsecondary settings. In many cases, 
a policy may already exist within an institute of higher education's (IHE) code of conduct for students and faculty, and this can serve as a starting point to create more robust support systems for SWDs in EFL programs specifically.

If an institutional policy does not already exist, then one specific to an individual program or department must be created from scratch. Language program leaders in this position can look to similar institutions' policies for examples, as well as refer to the International Classification of Functioning, Disability and Health (World Health Organization, 2002) or theoretical models of inclusive educational environment, one that provides equal opportunities for learning for all students, as a starting point. Hurtado et al. (2012) and Vaccaro et al. (2015) created two such models with postsecondary settings in mind.

Whether modified from existing policy or created, how SWDs are regarded within the given context should be articulated clearly and inclusively in writing. These guidelines should accord with the law and be made official at the highest possible level within the IHE. It is crucial that any such policy be clear and visible to all students, faculty, and staff. In postsecondary environments, such transparency can help prospective students choose the right school or department for them, as well as help develop their independence and self-determination as learners and social participants on campus (Hadley, 2011). Furthermore, transparency helps hold teachers and administrators accountable, as other stakeholders will be able to identify when these service providers are not optimally implementing support systems.

Increased visibility also means making policies available and easy to find both online and in print. In EFL contexts, this may require translation so that all stakeholders can understand them fully. When wording policies on regarding SWDs, it is important to be deliberate in the terminology used. Inclusive, neutral language conveys respect for all students and prevents othering of persons with disabilities (World Health Organization, 2002). Widely accepted terminology will help ensure effective and responsive functioning of support systems once they are fully established (Hamayan et al., 2013). In order to ensure full accountability, there should also be a highly visible procedure for students or other stakeholders to issue a complaint or request for revision to support plans without fear of reprisal. 


\section{Step 2. Identify and determine the availability of resources}

Once broader policies have been drafted, taking a full inventory of available resources for supporting SWDs is the next logical step. Such resources are easiest to identify and determine by beginning at the institutional level. There may be an existing support office or department dedicating to serving SWDs on campus, for instance. The exact nature of the services provided, and their transferability to language classrooms, should also be inventoried and detailed. In many postsecondary settings, departments with faculty specializing in fields from psychology to social welfare to occupational therapy may also prove helpful in establishing support systems for SWDs enrolled in EFL courses. Finally, resources within one's own department should not be overlooked. If EFL faculty have had training or experience teaching SWDs, these teachers can help support SWDs within the department, as well as provide training to other faculty members less versed in their particular knowledge area. Such expertise might go unnoticed if faculty members are not explicitly asked about prior training or experience teaching or working with persons with disabilities.

After an inventory of institutional resources has been created, it is time to look outside of the IHE for potential resources. For example, there may be community resources adjacent to campus that can be utilized in creating support systems. Communities of practice such as academic organizations or special interest groups may also be able to provide resources for SWDs and their teachers. Practitioners should be creative and thorough in their efforts to locate resources.

\section{Step 3. Identify and remove barriers in the learning environment}

Practitioners should adopt an interactional model of disabilities, one that foregrounds the notion that environmental barriers, and not the disability itself, impair an individual's ability to interact with that environment. This is preferable to a deficit model, which considers the disability itself 
as the barrier. By taking an interactional view, practitioners can better focus on identifying and removing barriers, as well as investigate and reflect on how SWDs interact with every aspect of their learning environment (Kormos, 2017). In this way, an interactional model promotes preventative, rather than corrective, interventions on curriculum, lesson, and materials design, and it also allows for the creation of more holistic, premeditated standards of teaching and learning outcomes. When SWDs encounter an environmental barrier on the way to realizing course or lesson aims, practitioners should critically examine the nature of the barrier and determine the best way to remove or minimize it.

It is likely that language program administrators and EFL teachers will not be able to immediately identify all barriers present in the learning environment and curriculum, though many common barriers can be anticipated and removed in advance of a student entering that environment. Two examples include the presence of serif fonts, which can be a barrier to students with dyslexia, or red ink, chalk, or markers, which can be barriers to students with color blindness. These barriers are easy enough to remove, but many others are not. Furthermore, barriers can be highly specific to the student or context and may emerge over time. As such, practitioners would do well by their students to remain attentive and objective in reflecting on all aspects of the learning environment, including but not limited to materials design, classroom layout, and classroom instruction and assessment.

Here, the Universal Design for Learning (UDL) Design Cycle (Rao \& Meo, 2016; Torres \& Rao, 2019) provides useful guidance. This cycle describes six easy-to-follow steps, including the identification and removal of barriers, as well as reflection on what works and what further environmental or instructional changes may be needed for SWDs to achieve their stated goals. Practical UDL guidelines that can inform EFL lesson design and delivery are available online (CAST, 2018).

\section{Step 4. Assign clear roles and responsibilities for leadership}

Effective leadership is paramount to creating effective procedures for delivering service provisions and making decisions with respect to 
curricular and instructional accommodation for SWDs (Furney et al., 2005). While EFL teachers may be highly invested in providing a continuum of services and conducting inclusive lessons, it is ultimately the responsibility of department or school leadership to ensure that students' needs are being met. A decentralized leadership with two or more roles sharing key responsibilities is recommended to help safeguard the prompt and appropriate execution of those responsibilities.

There are a number of resources available to aid language program leaders in the articulation and assignment of service provisions for SWDs. Loreman (2007), for instance, described seven pillars of support for inclusive education: 1) Developing positive attitudes; 2) Supportive policy and leadership; 3) School and classroom processes grounded in research-based practice; 4) Flexible curriculum and pedagogy; 5) Community involvement; 6) Meaningful reflection; 7) Necessary training and resources.

\section{Step 5. Create a framework for service delivery}

No single framework will work in every postsecondary context, as environmental factors often dictate the nature of service provisions, as well as the specifics and extent of their delivery in EFL curricula. Therefore, context-specific frameworks should be created. Once the previous four steps have been completed, it will be possible to draft a set of procedures that can then be organized and sequenced to create a framework of inclusive, barrier-free, and responsive service delivery that best exploits existing resources in accordance with legal requirements and institutional or departmental policy.

Ideally, the existence of a framework will precede its necessity. As often happens, however, programs can encounter student needs that test the limits of the program as-is, and the need for a framework becomes apparent too late to fully accommodate these needs. In these cases, it may be helpful to begin with an existing framework and modify it, rather than create one from scratch. Young, Schaefer, and Lesley (2019) successfully used such an approach in a postsecondary EFL setting, and there are a number of frameworks from disparate teaching contexts which can be used as starting points. Examples include Ortiz 
and Yates (2001), Scott et al. (2003), and Test et al. (2005). Taking this approach should not be done at the expense of the other guidelines described here, as providing truly inclusive support systems involves careful and conscious deliberation of the values underlying the instructional environment, as well as a sincere investment in the learning outcomes and educational experience of all students who enter that environment.

Frameworks must also be responsive. This means open and constantly utilized channels of communication between all stakeholders, including but not limited to the students, teachers, and administrators. Practitioners in EFL contexts with international faculty and staff should be wary that intercultural differences in communicating responsibilities and expectations can problematize communication between stakeholders (Young, 2019). However, clearly articulating roles and responsibilities for all stakeholders when following Step 4 can help minimize this problem.

Administrators at the senior management level are generally the furthest removed from students' actual experiences in the class, yet decisions regarding service delivery often come from this level. Thus, such stakeholders often become de facto gatekeepers, and it can be agonizing for the teachers who interact with students on a regular basis to await a decision when they can respond to a student's emergent needs much more rapidly, specifically, and nimbly. Attributing decision-making power to junior level administrators or teachers within part of the framework, as well as providing systematized training and support for faculty, can help counteract this potential problem. Stakeholders can also conduct a collaborative, formal post-term review of the appropriateness and efficacy of decision attribution and execution to improve these aspects of service delivery, as well as further solidify trust and open channels of communication between stakeholders.

No matter how carefully constructed, frameworks have limitations. For instance, it may be necessary to acknowledge context-specific barriers that cannot be removed. This is far from ideal but is a practical truth in many teaching contexts. One significant challenge common in postsecondary settings is the initial identification of SWDs and their needs. This is due to the fact that, in many such cases, students must self-identify to the IHE in order to receive support, and so 
there is likely an unknown number of unidentified SWDs enrolled in any given postsecondary learning environment. With respect to EFL contexts, differentiation of hidden disabilities from more general language learning difficulties is confounded by the presence of unidentified SWDs, which can present an additional challenge to practitioners.

\section{Step 6. Include a provision for post-implementation evaluation}

This step is easily overlooked, but it is of the utmost importance to ensuring the continued development and responsiveness of any structured support. Evaluative tools transform an otherwise static set of procedures into a dynamic and iterative one. If a disruption in the continuum of services being delivered to SWDs is identified, then it can be treated. No system should be assumed to be perfect, and as learning environments change and new students enter them, support systems must respond accordingly.

Revisions to any framework or standard operating procedure should be data-driven (Furney et al., 2005), and so evaluation must include accurate and reliable data collection. This may include instruments such as grade and retention analysis (Scott \& Edwards, 2012; Wessel et al., 2009; Young et al., 2019), surveying students (Finn, 1998; Schelly et al., 2011), surveying teachers (Young \& Schaefer, 2019), observing teachers' use of inclusive practice in the classroom (Sharma \& Sokal, 2016), or any other method that informs the practice of providing support to SWDs.

\section{Step 7. Offer opportunities for professional growth and creation of expertise}

There is ample research suggesting that training teachers to implement inclusive practice does indeed prepare them to teach students with diverse learning needs (Sharma et al., 2008). Additionally, positive attitudes towards, and understanding of, inclusive practice may both 
predict the presence of inclusive practices in the classroom (Sharma \& Sokal, 2016), and contribute to successful learning and retention of SWDs (Park et al., 2012). Unfortunately, language teachers too often fail to help SWDs overcome barriers to learning as a result of their general lack of training with respect to special education (Kormos \& Smith, 2012) or discriminatory attitudes towards SWDs in their classrooms (Gallego \& Busch, 2015).

While many teachers may earnestly wish to provide classroom accommodations to SWDs, they may simply not know how to go about it (Jensen et al., 2004). It is worthwhile, therefore, for language program leaders to create and offer professional development opportunities for their EFL faculty to become familiar with, if not proficient in, the implementation of inclusive practice and accommodation of different types of learner differences. Getzel et al. (2003) note that professional development regarding inclusive practice may be hindered by scheduling and time constraints, as well as a lack of perceived urgency and incentives for teachers, though these hindrances can be mitigated by emphasizing faculty ownership, encouraging collaboration among teachers, and incentivizing involvement in training programs (Reder et al., 2009).

Professional development opportunities can take multiple forms, from online trainings with financial incentives (Hsiao et al., 2019) to dual-focused workshops on traditional approaches to disability and universal design (Scott \& Edwards, 2012). Existing models for professional development with specific regard to postsecondary EFL contexts include a teacher-driven and collaborative cycle of inquiry (Turner et al., 2018), collaboration between EFL teachers and special educational needs coordinators (Lowe, 2016a; 2016b), training by specialists in external departments within the same IHE (Young et al., 2019), and a cascading model of knowledge transmission in which more experienced teachers share their acquired expertise with less experienced ones (Lowe, 2016a; Young \& Schaefer, 2019; Young et al., 2019).

Aside from such organized efforts, leadership can encourage faculty to be more involved with wider communities of practice to supplement their own lack of understanding around inclusive practice and the intersection of language learning and special education. This involvement might take the form of reading academic papers, attending 
conferences or workshops, taking online training courses, or engaging relevant communities online. Such professional development efforts may include incentives like increased prospects for promotion, pecuniary remuneration, or professional recognition for effort made (Reder et al., 2009). Naturally, leadership should practice what they preach and lead by example.

\section{Step 8. Share best practices with practitioners in other contexts}

A strong community of practice is essential for uniting practitioners and sharing best practices across contexts. In sharing our own challenges and best practices, we are able to help others and receive help in return. Such collaboration and information sharing will have an overall net benefit for SWDs who are studying English as a foreign language, as well as for the field of English language teaching more generally. An unknown number of postsecondary EFL practitioners around the world are struggling to serve students with disabilities in their classrooms and courses, and they could use your help. It is important to bear in mind, however, that no two postsecondary EFL contexts are the same, and lessons learned from one will not immediately transfer to another. These differences only highlight the need for collaboration.

\section{Conclusion}

This paper introduced eight steps to establish support systems for language learners with disabilities. While these guidelines may be applicable in a variety of settings, they were crafted with postsecondary EFL contexts specifically in mind. This was due to the fact that these teaching environments often lack established protocols and procedures for providing support for SWDs. If followed in total, the steps outlined here become dynamic and iterative, and will include built-in accountability checks. This ensures that support systems can continue to improve and respond to the evolving needs of a student population. 
In addition to enacting these on-the-ground measures, English language teachers and program leaders would do well to reach a mutual understanding of how best to continue the discussion around the myriad issues that extend from the intersection of language learning and special education. This includes, but is by no means limited to, agreeing upon a paradigm that best bridges these two educational domains to unite communities of practice and best serve all students. In the meantime, English language teachers should remain committed, methodical, and objective in their delivery of services to SWDs, as well as in their reflection on the efficacy and appropriateness of those services.

\section{References}

Adams, M. (2016). Pedagogical foundations for social justice education. In M. Adams, L. A. Bell, D. J. Goodman, \& K. Y. Joshi (Eds.), Teaching for diversity and social justice (pp. 27-54). Routledge.

CAST. (2018). Universal design for learning guidelines, version 2.2. http://udlguidelines.cast.org

Chiwandire, D., \& Vincent, L. (2019). Funding and inclusion in higher education institutions for students with disabilities. African Journal of Disability, 8, 1-12. http://doi.org/10.4102/ajod.v8i0.336

Finn, L. L. (1998). Students' perceptions of beneficial LD accommodation and services at the postsecondary level. Journal of Postsecondary Education and Disability, 13, 46-67. https://www.ahead.org/professional-resources/publications/jped/archived-jped/jped-volume-13

Furney, K. S., Aiken, J., Hasazi, S., \& Clark/Keefe, K. (2005). Meeting the needs of all students: Contribution of effective school leaders. Journal of School Leadership, 15(5), 546-570. https://doi. org/10.1177/105268460501500504

Gallego, M., \& Busch, C. (2015). Towards the inclusion of students with disabilities: Accessibility in language courses. Innovative Higher Education, 40(5), 387-398. http://doi.org/10.1007/s10755-015-9321-z

Getzel, E. E., Briel, L. W., \& McManus, S. (2003). Strategies for implementing professional development activities on college campuses: Find- 
ings from the OPE founded project sites (1999-2002). Journal of Postsecondary Education and Disability, 17, 59-78. https://files.eric.ed.gov/ fulltext/EJ876003.pdf

Hadley, W. M. (2011). College students with disabilities: A student development perspective. In W. S. Harbour \& J. W. Madaus (Eds.), Disability services and campus dynamics (pp. 77-82). Wiley.

Hamayan, E., Marler, B., Sanchez-Lopez, C., \& Damico, J. (2013). Special education considerations for English language learners: Delivering a continuum of services (2nd Ed.). Caslon Publishing.

Hsiao, F., Burgstahler, S., Johnson, T., Nuss, D., \& Doherty, M. (2019). Promoting an accessible learning environment for students with disabilities via faculty development. Journal of Postsecondary Education and Disability, 32, 91-99. https://files.eric.ed.gov/fulltext/EJ1217448.pdf

Hurtado, S., Alvarez, C. L., Guillermo-Wann, C., Cuellar, M., \& Arellano, L. (2012). A model for diverse learning environments: The scholarship on creating and assessing conditions for student success. In J. C. Smart \& M. B. Paulsen (Eds.), Higher education: Handbook of theory and research, volume 27 (pp. 41-122). Springer.

Jensen, J. M., McCrary, N., Krampe, K., \& Cooper, J. (2004). Trying to do the right thing: Faculty attitudes toward accommodating students with learning disabilities. Journal of Postsecondary Education and Disability, 17, 81-90. https://files.eric.ed.gov/fulltext/EJ876004.pdf

Kormos, J. (2017). The effects of specific learning difficulties on processes of multilingual language development. Annual Review of Applied Linguistics, 37, 30-44. https://doi.org/10.1017/S026719051700006X

Kormos, J., \& Smith, A. M. (2012). Teaching languages to students with specific learning differences. Multilingual Matters.

Loreman, T. (2007). Seven pillars of support for inclusive education. International Journal of Whole Schooling, 3(2), 22-38. https://files.eric.ed.gov/ fulltext/Ej847475.pdf

Lowe, R. (2016a). Special education needs in English language teaching: Towards a framework for continuing professional development. ELTED, 19, 23-31. http://www.elted.net/uploads/7/3/1/6/7316005/4_vol_19_ lowe.pdf

Lowe, R. (2016b). Special needs training in ELT programs as part of continuing professional development. OnCUE Journal, 9(1), 50-58. https:// jaltcue.org/files/OnCUE/OCJ9.1/OCJ9.1_pp50-58_OP_Lowe.pdf 
Morley, L., \& Croft, A. (2011). Agency and advocacy: Disabled students in higher education in Ghana and Tanzania. Research in Comparative and International Education, 6(4), 383-399. https://doi.org/10.2304/ rcie.2011.6.4.383

Ortiz, A. A., \& Yates, J. R. (2001). A framework for serving English language learners with disabilities. Journal of Special Education Leadership, 14(2), 72-80. http://case.readyhosting.com/documents/jsel/jsel_14.2.pdf\#page $=26$

Park, H. J., Roberts, K. D., \& Stodden, R. (2012). Faculty perspectives on professional development to improve efficacy when teaching students with disabilities. Journal of Postsecondary Education and Disability, 25, 377-383. https://files.eric.ed.gov/fulltext/EJ1002147.pdf

Rao, K., \& Meo, G. J. (2016). Using universal design for learning to design standards-based lessons. Sage Open, 6(4), 1-12. https://doi. org/10.1177/2158244016680688

Reder, M., Mooney, K. M., Holmgren, R., \& Kuerbis, P. (2009). Starting and sustaining successful faculty development programs at small colleges. In L. Nilson \& J. Miller (Eds.), To improve the academy: Vol. 27. Resources for faculty, instructional, and organizational development (pp. 267-286). Jossey-Bass.

Salmi, J. (2018). All around the world - Higher education equity policies across the globe. https://worldaccesshe.com/wp-content/uploads/2018/11/ All-around-the-world-Higher-education-equity-policies-across-theglobe-.pdf

Schelly, C. L., Davies, P. L., \& Spooner, C. L. (2011). Student perceptions of faculty implementation of universal design for learning. Journal of Postsecondary Education and Disability, 24, 17-30. https://files.eric. ed.gov/fulltext/EJ941729.pdf

Scott, S. S., \& Edwards, W. (2012). Project LINC: Supporting lecturers and adjunct instructors in foreign language classrooms. Journal of Postsecondary Education and Disability, 25, 253-258. https://files.eric.ed.gov/ fulltext/EJ994290.pdf

Scott, S. S., McGuire, J. M., \& Foley, T. E. (2003). Universal design for instruction: A framework for anticipating and responding to disability and other diverse learning needs in the college classroom. Equality \& Excellence in Education, 36(1), 40-49. https://doi. org/10.1080/10665680303502 
Sharma, U., Forlin, C., \& Loreman, T. (2008). Impact of training on pre-service teachers' attitudes and concerns about inclusive education and sentiments about persons with disabilities. Disability \& Society, 23(7), 773-775. https://doi.org/10.1080/09687590802469271

Sharma, U., \& Sokal, L. (2016). Can teacher's self-reported efficacy, concerns, and attitudes toward inclusion scores predict their actual inclusive classroom practices? Australasian Journal of Special Education, 40(1), 21-38. https://doi.org/10.1017/jse.2015.14

Test, D. W., Fowler, C. H., Wood, W. M., Brewer, D. M., \& Eddy, S. (2005). A conceptual framework of self-advocacy for students with disabilities. Remedial and Special Education, 26(1), 43-54. https://doi.org/10.11 77/07419325050260010601

Torres, C., \& Rao, K. (2019). UDL for language learners. CAST Professional Publishing.

Turner, M. W., Kasparek, N., \& McLaughlin, M. (2018). Teacher collaboration to support SEN learners. In P. Clements, A. Krause, \& P. Bennett (Eds.), Language teaching in a global age: Shaping the classroom, shaping the world (pp. 93-99). JALT.

UN News. (2016, September 1). Inclusive education vital for all, including persons with disabilities - UN rights experts. https://news.un.org/ en/story/2016/09/537952-inclusive-education-vital-all-including-persons-disabilities-un-rights-experts

Vaccaro, A., Daly-Cano, M., \& Newman, B. M. (2015). A sense of belonging among college students with disabilities: An emergent theoretical model. Journal of College Student Development, 56(7), 670-686. https:// muse.jhu.edu/article/597267

Wessel, R. D., Jones, J. A., Markle, L., Westfall, C. (2009). Retention and graduation of students with disabilities: Facilitating student success. Journal of Postsecondary Education and Disability, 21, 116-125. https:// files.eric.ed.gov/fulltext/EJ831430.pdf

World Health Organization. (2019). Disability. https://www.who.int/disabilities/en/

World Health Organization. (2002). Towards a common language for functioning, disability and health: ICF. http://www.who.int/classifications/icf/ icfbeginnersguide.pdf?ua=1 
Young, D. (2019). Providing reasonable accommodations for EFL students with disabilities in higher education in Japan. The Language Teacher, 43(5), 9-12. https://doi.org/10.37546/JALTTLT43.5-2

Young, D., \& Schaefer, M. Y. (2019). Collaborative support for students with disabilities. In P. Clements, A. Krause, \& P. Bennett (Eds.), Diversity and inclusion (pp. 136-142). JALT. https://doi.org/10.37546/JALTPCP2018-19

Young, D., Schaefer, M. Y., \& Lesley, J. (2019). Accommodating students with disabilities studying English as a foreign language. Journal of Postsecondary Education and Disability, 32, 311-319. https://files.eric. ed.gov/fulltext/EJ1236800.pdf 